\title{
COMPETENCES FOR THE FUTURE: A COMPARATIVE ANALYSIS OF AGILE CERTIFICATIONS
}

\author{
Alessandra Montenegro \\ Saga d.o.o., New Frontier Group, Belgrade, Serbia
}

\begin{abstract}
Worldwide project management organizations are constantly looking for the right set of skills for professionals in an agile world, training people to acquire them and offering different kinds of certifications. A person who wants to be certified in agile practice has a difficult choice when looking for a right certificate. This paper aims to provide a comparative analysis of the most eminent agile certifications in the global market in order to help people finding the most appropriate certification for them.
\end{abstract}

Key words: agile, competences, certifications.

\section{INTRODUCTION}

Digital era has created a huge demand for developing innovative project methodologies (Dybå \& Dingsøyr, 2008; Gil-Garcia, Helbig, \& Ojo, 2014). These methodologies were counterweight of traditional methodologies characterized as tightly regulated, bureaucratic and contradictory to the contemporary business environment (Chow \& Cao, 2008; Hoda, Noble, \& Marshall, 2008). It was necessary to go one step further and choose appropriate methodologies for success in the digital era. In the mid-1990s, agile project management methodologies emerged. Nowadays, there are many agile methodologies such as Scrum, Kanban, Lean, Extreme Programming etc. (Abrahamsson, Warsta, Siponen, \& Ronkainen, 2003). They all share some common values - focus on people and their interactions over processes and tools, product functionality beyond exhaustive documentation, collaborating with the customer beyond a firm grip on contract items, and constantly responding to changes rather than following a plan (Beck et al., 2001.). Further, new methodologies have required from personnel to develop a new set of skills, in order to deliver modern projects well (Highsmith, \& Cockburn, 2001). Recent research, conducted by the eminent consulting firm CEB, has shown that the position of a project manager in the IT industry is the most difficult-to-fill IT role generally (Matt McWha, 2016). Organizations are facing great difficulty to find adequate professionals for managing complex digital era projects. Traditional process-oriented project managers are no longer able to respond to the demands of innovative projects (Hoda et al., 2008) For that reason, worldwide project management organizations are constantly looking for the right set of skills for professionals in an agile world, training people to acquire them and offer different kinds of certifications.

This paper aims to provide a comparative analysis of the most eminent agile certifications in the global market in order to help people finding the most appropriate certification for them. The paper presents agile certificates from 9 well-known certification bodies: PMI, IPMA, APMG, Strategyex, ICAgile, Scrum.org, Scrum Alliance, Scaled Agile Academy and IAPM. Because some organizations offer a variety of agile certifications, the chapters in this paper are named by the organization provided certificate rather than by a specific certificate. Although the focus of the research was on certifications for project managers (and similar positions), the paper also provides a review of certifications for other roles in an agile project environment but does not explain them in detail. The last chapter compares the certificates according to the following criteria: an organization that offers certification, name of the certification, prerequisites/required courses, the structure of the exam, certification maintenance and the price of certification.

Corresponding author. Email: alessandramontenegro9@gmail.com 


\section{PMI - THE AGILE CERTIFIED PRACTITIONER (PMI - ACP)}

The Project Management Institute (PMI) is a global nonprofit professional organization for project management. PMI is developing standards, research, publication, hosting conferences and providing accreditation in project management (PMI, 2019.).

The Agile Certified Practitioner (PMI-ACP) is one of several certification types from the Project Management Institute (PMI). It is also the only certification for agile project management and fastest-growing certification of this institute (PMI, 2019). While most agile certificates are scrum-based, the advantage of PMI-ACP certification is that it includes many agile approaches withal Scrum, such as Kanban, Lean, Extreme Programming (XP) and test-driven development (TDD).

Also, comparing to other agile certifications based solely on training and exams, the ACP exam requires trainees to have real experience in project management and managing agile projects. Prerequisites are 2000 hours working on projects, 1500 hours working on agile project teams or with agile methodologies as well as 21 hours of training in agile practices (PMI, 2019). The exam consists of 120 multiple-choice questions and the available time is three hours. The exam can be in a paperbased or a computer-based format. The price depends on the testing format and the PMI membership and is in the range from $385 \$$ for paper-based member testing to $\$ 495$ for computer-based testing of PMI non-members. Those who achieve the certification Agile Certified Practitioner must earn 30 professional development units (PDUs) in agile topics every three years to maintain their status.

\section{IPMA - AGILE LEADER CERTIFICATIONS}

International Project Management Asociation (IPMA) is the world's first project management association founded in 1965 . (IPMA, 2019). IPMA is promoting the development of project management competencies and expanding relationships with professionals, corporations, government agencies, universities etc.

In the field of agile practices, IPMA offers Agile Leader Certification which consists of 4 levels: (A) IPMA Certified Agile Organisational Leader, (B) IPMA Certified Senior Agile Leader, (C) IPMA Certified Agile Leader, (D) IPMA Certified Agile Associate. The IPMA certification scheme is based on the global competence standard - ICB4. For the people who want to take the IPMA Certified Agile Associate (Level D), it is not necessary to have experience in agile practice, while other levels of certifications require at least 30 months of practical experience in managing agile projects. The exam consists of written test and interview. The price of the certification is 1000 euro for Level C.

\section{APMG INTERNATIONAL CERTIFICATIONS}

APMG International is a global accreditation organization offering a number of certification in different fields such as Aerospace, Business Change, Risk \& Benefits, Cyber Security, IT Governance \& Service and Projects. All agile certificates from APMG are listed below: (1) Agile Change Agent certification, (2) Agile Digital Services Foundation certification, (3) Agile Digital Services Practitioner certification, (4) Agile Business Consortium Scrum Master certification, (5) Agile Project Management Foundation Certification, (6) Agile Project Management Practitioner certification, (7) Agile Program Management Foundation certification, (8) Agile Business Analyst Foundation certification, (9) Agile Business Analyst Practitioner certification.

For the purposes of this paper, only certificates relating to project management will be presented. Agile Project Management Foundation certificate is intended for project managers and agile team members looking to become Agile Project Managers. On the other hand, Agile Project Management Practitioner is a more advanced level of certification and it is intended for people who already have an Agile PM Foundation certificate. Agile PM Foundation is a closed book exam. It consists of 50 multiple choice questions and the maximum duration of the test is 40 minutes. 
Agile PM Practitioner is open book objective examination. It consists of 4 questions and it takes 2.5 hours. Both exams require 50\% to pass the exam. The price of the Agile Project Management Foundation certification is $£ 218$, while the price of the Agile Project Management Practitioner is $£ 330$.

Agile Program Management certification is different from Agile Project Management certification and has only a Foundation level of certification. This exam is for Programme Managers, PMO Managers, Risk Managers, Procurement professionals and Senior business people who have responsibility for programmes (APMG International, 2019.) The exam structure is the same as Agile PM Foundation exam. Agile Business Consortium Scrum Master is intended for anyone involved in product development using the Scrum framework. It is based on The Scrum Guide. The exam consists of 50 multiple-choice questions - no recertification requirements. APMG Scrum Master certification does not expire.

\section{STRATEGYEX CERTIFICATES IN AGILE}

Online learning company Strategy Execution (formerly known as ESI International, est. 1981.), in partnership with Duke University, offers many courses in agile practice. They believe that powerful strategic work can be achieved through a series of projects, hereof people running projects must possess the right set of competencies to ensure project success (Strategyex, 2019).

Strategy Execution offers many two levels of certification: Foundational and Professional certification in agile practice. Certification is organized in a way that people who want Foundational certificate must choose five courses, and Professional certificate requires taking nine courses from the listed below: Fundamentals of Lean and Agile, Continuous improvement with Lean and Kanban, Iterative Delivery with Scrum and Kanban, Eliciting and Managing Requirements, Establishing a Business Mindset, Managing Project, Facilitation Techniques for Business Analysis, High-Impact Communication, Critical Thinking and problem solving, Fundamentals of DevOps, Project Leadership and Management and Communication. The exact price of certifications is not specified because it depends on the chosen courses. The price of one course is from $1195 \$$ to $1795 \$$. As it is mentioned above, it is necessary to attend 5 courses for Foundational and 9 courses for Professional certificate.

\section{INTERNATIONAL CONSORTIUM FOR AGILE (ICAGILE) CERTIFICATIONS}

The International Consortium for Agile is an accrediting agency that offers comprehensive Agile certifications across all agile 'flavours". All ICAgile certificates are listed below: (1) Agile Fundamentals, (2) Agile Coaching (Agile Team Facilitation, Agile Coaching, Expert in Agile Coaching), (3) Agile Engineering (Agile Programming, Agile Software Design, Expert in Agile Engineering), (4) Agile Testing (Agile Testing, Agile Test Automation, Expert in Agile Testing), (5) Business Agility (BA Foundations, Agile Talent, Agile Finance, Agile Leadership, Agile Marketing, Expert in BA), (6) DevOps (Foundations in DevOps, Implementation DevOps, Expert in DevOps), (7) Delivery Management (Agile Project and Delivery Management, Delivery at Scale, Expert in Delivery Management), (8) Enterprise Management (Agility in the Enterprise, Coaching Agile Transitions, Expert in Enterprise Coaching) and (9 )Product Ownership (Agile Product Ownership, Enterprise Product Ownership).

Agile Project and Delivery Management certificate is based on core components of agile project management and on providing course attendees with techniques for successful Lean and Agile implementation. The certification consists, of course, lasting 14-21 hours. The cost of the certification is \$60 (ICAGILE, 2019).

\section{SCRUM.ORG CERTIFICATIONS}

Scrum.org is a global organization, founded 2009 by Ken Schwaber, the co-creator of Scrum. Scrum.org provides pieces of training, assessments and certifications for successful Scrum implementation. Compared to other 
organizations mentioned above in this paper, that cover different agile methods, Scrum.org is promoting Scrum exclusively. Following Scrum Guide, there are 3 roles within the scrum - Scrum Master, Product Owner and Developer (Schwaber, \& Sutherland, 2017). For each role, the Scrum.org offers various levels of certification and there are also certificates for a scaled scrum, scrum with Kanban and agile leadership.

Scrum.org offers three levels of certification for the role of Scrum master - fundamental, advanced and distinguished (PSM I, PSM II and PSM III). People who have passed Professional Scrum Master I Assessments proves a fundamental level of Scrum, understanding Scrum as described in the Scrum Guide and now how to apply Scrum in Scrum Teams. The cost of this exam is $\$ 150$ USD. The exam consist of 80 questions (Multiple Choice, Multiple Answer and True/False), duration of the exam is 60 minutes; the passing score is $85 \%$. People who want to upgrade their scrum knowledge can take the PSM II exam. This exam demonstrates an advanced level of Scrum knowledge and its implementation in complex situations. The price of the PSM II exam is 250\$. The exam consist of 30 questions (Multiple Choice, Multiple Answer and True/False), duration of the exam is 90 minutes, passing score is $85 \%$. Finally, the Professional Scrum Master level III (PSM III) assessment is available to anyone who has passed the PSM I and PSM II assessments. This exam demonstrates a distinguished level of Scrum and a deep understanding of Scrum in a variety of complex and organizational situations. The cost of PSM III is \$500 USD. The exam structure is a combination of 34 Multiple Choice questions and essay. Time limit is 120 minutes. Passing score is also $85 \%$. For all these exams there are no prerequisites in terms of mandatory courses but the Scrum.org offers variety optional courses for those who want it. Once passed the Scrum Master exam is unlimited, no need for recertification. Similar structure to the scrum master certification is also certification for Product Owners. There are three levels of Professional Scrum Product Owner Assessments- PSPO I, PSPO II and PSPI III. Also, Scrum.org serves certifications for Scrum Developers, Scaled Professional Scrum (available to anyone who wishes to validate knowledge of the scaling Scrum), Assessments for Professional Scrum with Kanban and Assessments for Professional Agile Leadership.

\section{SCRUM ALLIANCE CERTIFICATIONS}

Scrum Alliance is an organization that supports global adoption and effective practice of Scrum. The Scrum Alliance offers three types of certification: (1) Certifications by Scrum Team Role, (2) Guide Level Certifications and (3) Agile Leadership Certification.

The first group of certifications is very similar to Scrum.org certification program, and it is divided by the Scrum team roles - Scrum Master, Product Owner and Developer. Certification for Scrum Master consists of three levels: a) Certified Scrum Master, b) Advanced Certified Scrum Master and c) Certified Scrum Professional-ScrumMaster. The classification for the Product Owner was done in the same way: a) Certified Scrum Professional-Product Owner, b) Advanced Certified Scrum Product Owner, c) Certified Scrum Professional-Product Owner, while the certification for the scrum developer has two levels a) Certified Scrum Developer and b) Certified Scrum Professional. Guide Level Certifications are designed to authorize coaches and trainers as educators, mentors, and thought leaders in agile principles and the Scrum framework and to become a Certified Agile Coach or a Certified Scrum Trainer. The Scrum Alliance Certified Agile Leadership (CAL) program is a unique two-part education (CAL I + CAL II) and practicebased program to develop agile leadership competency and maturity (Scrum Alliance, 2019).

Unlike Scrum.org certifications that do not require courses, attending courses is mandatory for possessing a Scrum Alliance certificate. In fact, the courses are included in the price of certification, but that price is much higher than with the Scrum.org. For example, the price of Certified Scrum Master certification is around $\$ 1,547$ per course and it depends on the country. After receiving certification, there is a $\$ 250$ annual renewal fee. Price for Advanced 
Certified Scrum Master certification is around $2800 \$$ and person who take the exam should have at least 12 months of work experience specific to the role of Scrum Master. Advanced Certified Scrum Master should have at least 24 months of work experience, and the price of certification is around 3500\$.The price for all courses includes 2 years membership fee with Scrum Alliance.

\section{SCALED AGILE ACADEMY CERTIFICATIONS}

Scaled Agile Framework (SAFe) is a global framework for enterprise agility. The Scaled Agile Academy offers 13 courses: (1) SAFe 4 Program Consultant (SPC), (2) SAFe Agilist (SA), (3) SAFe 4 Practitioner (SP), (4) SAFe 4 Scrum Master (SSM), (5) SAF Advanced Scrum Master (SASM), (6) SAFe 4 Release Train Engineer (RTE), (7) SAFe 4 Product Owner/Product Manager (POP), (8) SAFe 4 DevOps Practitioner (SDP), (9) SAFe 4 Architect (ARCH), (10) SAFe Agile Software Engineering (ASE), (11) SAFe Agile Product and Solution Management (APSM), (12) Lean Portfolio Management (LPM), (13) SAFe Government Practitioner. For the purposes of this paper, only SAFe 4 Scrum Master (SSM) and SAFe Advanced Scrum Master (SASM) certifications will be described in more detail.

SAFe 4 Scrum Master (SSM) certification includes a two-day course. It is intended for people who want to perform the role of scrum master regardless of experience. First exam attempt is included in the price of the course if the exam is taken within 30 days of course completion. Each retake costs $\$ 50$. The exam consists of 45 multiple choice questions; attendees have 90 minutes available and $73 \%$ is a passing score. SAFe Advanced Scrum Master (SASM) certification is intended for existing scrum masters. There are no prerequisites for taking the exam, but it is desirable to have some of the scrum master certifications such as Certified Scrum Master (CSM) or Professional Scrum Master (PSM) certification. The exam consists of 60 multiple choice questions; attendees have 120 minutes available and $70 \%$ is the passing score. The price of this certification is $\$ 995$ per course and the first exam attempt is free. After receiving certification, there is a $\$ 100$ annual renewal/membership fee.

\section{IAPM CERTIFICATIONS}

The International Association of Project Managers (IAPM), association and certification body for project managers, offers 8 levels of certification for project managers. Regarding agile certifications, there are 3 levels (1) Certified Junior Agile Project Manager, (2) Certified Agile Project Manager and (3) Certified Senior Agile Project Manager. First two categories are intended for people with no necessary project management experience while for Senior Agile certification, one must possess experience in managing projects. For passing the Junior Project Manager exam, it is necessary to have $65 \%$ of the 40 questions correct. Time limit is 35 minutes. The Agile Project Manager exam requires $65 \%$ of the 120 questions to be answered correctly within 80 minutes (it is the same for the Senior Project Manager exam). The price of listed certificates is $35 \mathrm{CHF}, 183$ $\mathrm{CHF}$ and $237 \mathrm{CHF}$ respectively. IAPM certifications do not require recertification.

\section{COMPARATIVE OVERVIEW OF AGILE CERTIFICATIONS}

The following table presents a comparative overview of the agile certifications listed in this paper. Certificates are compared by six criteria: (1) organization that offers certification, (2) name of the certification, (3) prerequisites/required courses, (4) structure of exam, (5) certification maintenance and (6) the price of certification. 
Table 1: Comparative overview of agile certifications

\begin{tabular}{|c|c|c|c|c|c|}
\hline Org. & $\begin{array}{c}\text { Name of } \\
\text { certification }\end{array}$ & Prerequisites/Courses & $\begin{array}{c}\text { Exam } \\
\text { structure }\end{array}$ & Maintainance & $\begin{array}{l}\text { The price of } \\
\text { certification }\end{array}$ \\
\hline PMI & $\begin{array}{l}\text { Agile Certified } \\
\text { Practitioner } \\
\text { (ACP) }\end{array}$ & $\begin{array}{c}2,000 \text { hours working on } \\
\text { projects } \\
1,500 \text { hours working on } \\
\text { agile projects } \\
21 \text { hours of training in } \\
\text { agile practices. }\end{array}$ & $\begin{array}{l}120 \text { multiple- } \\
\text { choice } \\
\text { questions } \\
3 \text { hours }\end{array}$ & $\begin{array}{c}30 \text { PDUs in agile } \\
\text { topics every three } \\
\text { years }\end{array}$ & $\begin{array}{c}\text { From } 385 \$ \text { to } \\
495 \$\end{array}$ \\
\hline IPMA & $\begin{array}{c}\text { (A) IPMA } \\
\text { Certified Agile } \\
\text { Organisational } \\
\text { Leader, } \\
\text { (B) IPMA } \\
\text { Certified Senior } \\
\text { Agile Leader, } \\
\text { (C) IPMA } \\
\text { Certified Agile } \\
\text { Leader, (D) } \\
\text { IPMA Certified } \\
\text { Agile Associate }\end{array}$ & $\begin{array}{c}\text { No prerequisites for level } \\
\text { D. } \\
\text { For level A, B, C: } \\
\text { at least } 30 \text { months of } \\
\text { practical experience in } \\
\text { managing agile projects. }\end{array}$ & $\begin{array}{l}\text { written test } \\
\text { exam }\end{array}$ & $\begin{array}{l}\text { Re-certification } \\
\text { after } 5 \text { years }\end{array}$ & 1000 euro \\
\hline $\begin{array}{c}\text { ICAgi } \\
\text { le }\end{array}$ & $\begin{array}{l}\text { Agile Project } \\
\text { and Delivery } \\
\text { Management } \\
\text { certificate }\end{array}$ & l & $\begin{array}{c}\text { course } 14-21 \\
\text { hours }\end{array}$ & l & $60 \$$ \\
\hline
\end{tabular}

\begin{tabular}{|c|c|c|c|c|c|}
\hline Org. & $\begin{array}{c}\text { Name of } \\
\text { certification }\end{array}$ & Prerequisites & $\begin{array}{c}\text { Exam } \\
\text { structure }\end{array}$ & Maintainance & $\begin{array}{l}\text { The price of } \\
\text { certification }\end{array}$ \\
\hline \multirow[b]{3}{*}{ IAPM } & $\begin{array}{l}\text { Certified Junior } \\
\text { Agile Project } \\
\text { Manager }\end{array}$ & I & $\begin{array}{l}40 \text { questions } \\
35 \text { minutes }\end{array}$ & \multirow{3}{*}{$\begin{array}{l}\text { IAPM } \\
\text { certifications do } \\
\text { not require } \\
\text { recertification }\end{array}$} & $35 \mathrm{CHF}$, \\
\hline & $\begin{array}{l}\text { Certified Agile } \\
\text { Project Manager }\end{array}$ & I & $\begin{array}{l}120 \text { questions } \\
80 \text { minutes }\end{array}$ & & $183 \mathrm{CHF}$ \\
\hline & $\begin{array}{l}\text { Certified Senior } \\
\text { Agile Project } \\
\text { Manager }\end{array}$ & $\begin{array}{l}\text { Experience in managing } \\
\text { projects (not specified how } \\
\text { much experience is } \\
\text { necessary) }\end{array}$ & $\begin{array}{l}120 \text { questions } \\
80 \text { minutes }\end{array}$ & & $237 \mathrm{CHF}$ \\
\hline \multirow[b]{3}{*}{$\underset{\mathbf{G}}{\mathbf{A P M}}$} & $\begin{array}{l}\text { Agile Project } \\
\text { Management } \\
\text { Foundation }\end{array}$ & l & $\begin{array}{l}\text { Closed book } \\
\text { exam } \\
50 \text { multiple } \\
\text { choice } \\
\text { questions } 40 \\
\text { minutes }\end{array}$ & I & $£ 218$ \\
\hline & $\begin{array}{l}\text { Agile Project } \\
\text { Management } \\
\text { Practitioner }\end{array}$ & $\begin{array}{l}\text { Agile PM Foundation } \\
\text { certificate }\end{array}$ & $\begin{array}{l}\text { Open book } \\
\text { exam } \\
4 \text { questions } \\
2.5 \text { hours }\end{array}$ & I & $£ 330$ \\
\hline & $\begin{array}{l}\text { Agile Program } \\
\text { Management } \\
\text { Foundation }\end{array}$ & l & $\begin{array}{l}\text { Closed book } \\
\text { exam } \\
50 \text { multiple } \\
\text { choice } \\
\text { questions } 40 \\
\text { minutes. }\end{array}$ & I & $\begin{array}{l}\text { information } \\
\text { not found }\end{array}$ \\
\hline
\end{tabular}




\begin{tabular}{|c|c|c|c|c|c|}
\hline & $\begin{array}{l}\text { Agile Business } \\
\text { Consortium } \\
\text { Scrum Master }\end{array}$ & l & $\begin{array}{l}50 \text { multiple } \\
\text { choice } \\
\text { questions } 40 \\
\text { minutes. }\end{array}$ & I & $\begin{array}{l}\text { information } \\
\text { not found }\end{array}$ \\
\hline \multirow{2}{*}{$\begin{array}{l}\text { STRA } \\
\text { T- } \\
\text { EGY } \\
\text { EX }\end{array}$} & $\begin{array}{l}\text { Foundational } \\
\text { certification in } \\
\text { agile practice }\end{array}$ & requires taking five courses & $\begin{array}{l}\text { Courses and } \\
\text { exam }\end{array}$ & / & \multirow{2}{*}{$\begin{array}{l}\text { the exact price } \\
\text { depends on } \\
\text { the chosen } \\
\text { courses- the } \\
\text { price of one } \\
\text { course is from } \\
1195 \$ \text { to } \\
1795 \$\end{array}$} \\
\hline & $\begin{array}{l}\text { Professional } \\
\text { certification in } \\
\text { agile practice }\end{array}$ & requires taking nine courses & $\begin{array}{c}\text { Courses and } \\
\text { exam }\end{array}$ & / & \\
\hline
\end{tabular}

\begin{tabular}{|c|c|c|c|c|c|}
\hline Org. & $\begin{array}{c}\text { Name of } \\
\text { certification }\end{array}$ & Prerequisites & $\begin{array}{c}\text { Exam } \\
\text { structure }\end{array}$ & Maintainance & $\begin{array}{l}\text { The price of } \\
\text { certification }\end{array}$ \\
\hline \multirow[b]{3}{*}{$\begin{array}{c}\text { SCRU } \\
\text { M.ORG }\end{array}$} & PSM I & l & $\begin{array}{l}80 \text { Multiple } \\
\text { Choice } \\
\text { questions } \\
60 \text { minutes }\end{array}$ & I & $150 \$$ \\
\hline & PSM II & l & $\begin{array}{l}30 \text { Multiple } \\
\text { Choice } \\
\text { questions } \\
90 \text { minutes } \\
\end{array}$ & I & $250 \$$ \\
\hline & PSM III & I & $\begin{array}{c}\text { combination } \\
\text { of } 34 \text { Multiple } \\
\text { Choice } \\
\text { questions and } \\
\text { essay } \\
120 \text { minutes } \\
\end{array}$ & I & $500 \$$ \\
\hline \multirow{3}{*}{$\begin{array}{l}\text { SCRU } \\
\text { M } \\
\text { ALLIA } \\
\text { NCE }\end{array}$} & $\begin{array}{c}\text { Certified } \\
\text { Scrum Master }\end{array}$ & I & $\begin{array}{l}\text { courses } \\
\text { and } \\
\text { exam }\end{array}$ & Annual fee $\$ 250$ & $\begin{array}{c}\text { around } \$ 1,547 \\
\text { depends on the } \\
\text { country }\end{array}$ \\
\hline & $\begin{array}{c}\text { Advanced } \\
\text { Certified } \\
\text { Scrum Master }\end{array}$ & $\begin{array}{l}\text { at least } 12 \text { months of work } \\
\text { experience specific to the } \\
\text { role of Scrum Master }\end{array}$ & $\begin{array}{l}\text { courses } \\
\text { and } \\
\text { exam }\end{array}$ & Annual fee $\$ 250$ & $\begin{array}{c}\text { around } \\
2800 \$ \\
\text { depends on the } \\
\text { country } \\
\end{array}$ \\
\hline & $\begin{array}{c}\text { Certified } \\
\text { Scrum } \\
\text { Professional- } \\
\text { ScrumMaster }\end{array}$ & $\begin{array}{l}\text { at least } 24 \text { months of work } \\
\text { experience specific to the } \\
\text { role of Scrum Master }\end{array}$ & $\begin{array}{l}\text { courses } \\
\text { and } \\
\text { exam }\end{array}$ & Annual fee $\$ 250$ & $\begin{array}{c}\text { around } \\
3500 \$ \\
\text { depends on the } \\
\text { country }\end{array}$ \\
\hline \multirow{2}{*}{$\begin{array}{c}\text { SCALE } \\
\text { D } \\
\text { AGILE } \\
\text { ACAD } \\
\text { EMY }\end{array}$} & $\begin{array}{l}\text { SAFe } 4 \\
\text { Scrum Master } \\
\quad(\mathrm{SSM})\end{array}$ & & $\begin{array}{l}45 \text { multiple } \\
\text { choice } \\
\text { questions, } 90 \\
\text { minutes, } \\
73 \% \text { is } \\
\text { passing score }\end{array}$ & & $\$ 995$ \\
\hline & $\begin{array}{c}\text { SAFe } \\
\text { Advanced } \\
\text { Scrum Master }\end{array}$ & $\begin{array}{l}\text { desirable to have some of the } \\
\text { scrum master certifications } \\
\text { such as CSM or PSM }\end{array}$ & $\begin{array}{l}60 \text { multiple- } \\
\text { choice } \\
\text { questions, } \\
120 \text { minutes } \\
70 \% \text { is } \\
\text { passing score }\end{array}$ & & $\$ 995$ \\
\hline
\end{tabular}

Agile Certificate Professional certificate (PMI$\mathrm{ACP})$, compared to other certificates, has an affordable price, and also it is well known that PMI certificates are synonymous for respectability in the project management world. On the other hand, ACP certificate requires working experience in agile practice and it is not appropriate for people just beginning project management career. Also, 
ACP certificate requires continuously collecting PDUs.

The advantage of the IPMA Agile leader certifications is a 4-level structure. Level D IPMA certification does not require experience, and it is very convenient for young and new project managers. Also, there is no need for collecting PDUs and additional membership costs. Every five years certificate owner goes through a simple process of recertification (only proof that the certificate owner still meets the certification criteria). IAPM certification consists of 3 levels: certification for a junior agile project manager, agile project manager and senior agile project manager. These certifications are not expensive and first two levels do not require experience. Also, IAPM certifications do not require recertification. However, this certification is not so recognized in the world, such as IPMA`s and PMI's certifications (Toljaga-Nikolić, Obradović, Mihić, 2011). The advantage of APMG certification is that it has multiple levels and focus on both: agile practice in general and scrum as one of the agile frameworks. These certificates are in the middle price range, do not require prerequisites for the first levels and there are no conditions for maintenance (no re-certifications). Strategyx offers serious courses in the field of agile practice. The disadvantage of this type of certification requires many courses (5 for Foundational certification and 9 for Professional certification), it takes a lot of time and it is very expensive (the cheapest course is $1195 \$$ ). ICAgile also belongs to the group of cheaper certificates. In fact, this is a two-day course and after attending the course, the student receives a certificate. The certificate is not renewed and there are no conditions for attending the course. In terms of certifications for the scrum framework, the most famous certification bodies are the Scrum.org and the Scrum alliance. The Scrum Alliance is more expensive and requires some experience for higher levels of certification and also additional costs to maintain the certification. Scrum.org is cheaper and more convenient for people with no experience. Scurm.org does not require certificates renewal. Scaled Agile Academy also offers scrum certifications but its certificates are more expensive compared to the first two certification bodies but do not have the experience pre-requisites.

\section{CONCLUSION}

The most wanted certificates for agile practice nowadays are presented in this paper. All eminent certification bodies in the field of project management have in their palette agile certifications. A person who wants to take a certificate has a difficult choice when choosing the right certificate. The purpose of this paper was to help people who intend to be certified, making the right decision what certificate is the most appropriate for them. All the listed certificates have their advantages; it is just necessary to select the most appropriate certificate for each person. Beginners with no experience should start with some lightweight certifications such as ICAgile, Scrum.org or with lower levels of certification of other certification bodies, while professionals with experience can directly apply for certificates such ACP-PMI, or higher levels of certificates like IPMA level A, B or C.

\section{REFERENCES}

Abrahamsson, P., Warsta, J., Siponen, M. T., \& Ronkainen, J. (2003). New Directions on Agile Methods: A Comparative Analysis. Retrieved from http://dictionary.oed.com

APMG international, retrieved August 14 2019, from https://apmginternational.com/product/agilepgm

Beck, K., Grenning, J., Martin, R., Beedle, M., Highsmith, J., Mellor, S., Bennekum, A., Hunt, A., Schwaber, K., Cockburn, A., Jeffries, R., Sutherland, J., Cunningham, W., Kern, J., Thomas, D., Fowler, M., Marick, B. (2001). Manifesto for Agile Software Development. Retrieved August 17, 2019, from https://agilemanifesto.org/

Chow, T., \& Cao, D. B. (2008). A survey study of critical success factors in agile software projects. Journal of Systems and Software, $81(6)$, 961-971. https://doi.org/10.1016/j.jss.2007.08.020

Certifications by Scrum Team Role, retrieved August $12 \quad 2019, \quad$ from https://www.scrumalliance.org/get$\underline{\text { certified }}$ 
Dybå, T., \& Dingsøyr, T. (2008). Empirical studies of agile software development: A systematic review. Information and Software Technology. https://doi.org/10.1016/j.infsof.2008.01.0 06

Gil-Garcia, J. R., Helbig, N., \& Ojo, A. (2014). Being smart: Emerging technologies and innovation in the public sector. Government Information Quarterly, 31(S1), I1-I8. https://doi.org/10.1016/j.giq.2014.09.001

Highsmith, J., \& Cockburn, A. (2001, September). Agile software development: The business of innovation. Computer. https://doi.org/10.1109/2.947100

Hoda, R., Noble, J., \& Marshall, S. (2008). Agile project management. In New Zealand Computer Science Research Student Conference, NZCSRSC 2008 Proceedings (pp. 218-221). https://doi.org/10.1145/1101779.1101781

IAPM, retrieved August 12 2019, from https://www.iapm.net/en/certification/lev els-of-certification/certified-senior-agileproject-manager-iapm/

ICAgile, retrieved August 17 2019, from https://www.icagile.com/Find-a-

Class? regionId $=12 \&$ state $=\&$ province $=\& \mathrm{t}$ rackId=60

McWha, M. (2016). Reshaping the project manager role for the digital age, Retrieved August 10, 2019, form https://www.cio.com/article/3152049/res haping-the-project-manager-role-for-thedigital-age.html

PMI Agile Certified Practitioner (PMI-ACP), retrieved August 15 2019, from https://www.pmi.org/certifications/types/ agile-acp

Professional Scrum Training Courses, retrieved August 02 2019, from https://www.scrum.org/

Schwaber, K., \& Sutherland, J. (2017). The Scrum Guide ${ }^{T M}$ The Definitive Guide to Scrum: The Rules of the Game.

Scaled agile, retrieved August 14 2019, from https://www.scaledagile.com/certification /courses/safe-advanced-scrum-master/

Strategyex, retrieved August 14 2019, from https://www.strategyex.com/aboutstrategy-execution/about-us

The IPMA Agile Leader Certification, retrieved August 05 2019, from http://ipma.rs/index.php/ipma-agileleader-certification/

Toljaga-Nikolić, D., Obradović, V., \& Mihić, M. (2011). Certification for project managers by IPMA and PMI models through compliance with the requirements of ISO 17024:2003, Management, No. 59, p. 45-53. 